\title{
EVALUACIÓN DEL IMPACTO SOBRE EL MARGEN BRUTO DE UN CONJUNTO DE ESTRATEGIAS DE MANEJO EN LA ACTIVIDAD LECHERA
}

\author{
Rossler, N. ${ }^{1}$; GIUSIANO, J. ${ }^{2} \&$ BLANGetTI, D. ${ }^{3}$
}

\begin{abstract}
RESUMEN
Utilizando la metodología de estudio de caso se comparó el margen bruto de un tambo ubicado al oeste de la provincia de Córdoba, con su manejo habitual versus una situación hipotética mejorada del mismo. El objetivo fue evaluar el impacto económico de algunas estrategias de manejo que mejoran los indicadores productivos y reproductivos del sistema. Los problemas identificados están vinculados a cuestiones de manejo del rodeo en particular y del sistema en general: elevado porcentaje de rechazo y muerte de animales, bajas carga animal, relación VO/ VTy producción individual de leche, venta de animales en categorías regulares, elevadonivel de gastos sanitarios. La solución de estos problemas mediante la implementación de estrategias de manejo de bajo o nulo costo repercutió de manera positiva en el margen bruto, principalmente por un incremento en los ingresos. El margen bruto de la situación mejorada duplicó al margen bruto de la situación actual.
\end{abstract}

Palabras clave: manejo del rodeo lechero, margen bruto, caso de estudio.

\begin{abstract}
Impact assessment of dairy farm management strategies on gross margin. Gross margin of a dairy farm located west of Córdoba (Argentina), with its usual management, was compared versus its hypothetical improved scenario, using the methodology of case study. The objective was to evaluate the economic impact of some management strategies that improve the productive and reproductive system indicators. The problems identified were: high percentage of rejection and death of animals, low stocking, relationship VO/VT and individual production of milk, sale of animals in regular categories, high level of health costs. The solution of these problems by implementing management strategies with low or no cost, impacted positively on the gross margin, mainly due to an increase in revenue. The gross margin improved scenario, doubling the gross margin of the current situation.
\end{abstract}

Key words: dairy herd management, gross margin, case study.

1.- Docente-Investigador de la Facultad de Ciencias Agrarias, Universidad Nacional del Litoral (Administración de Organizaciones, Economía y Mercadeo Agroalimentario). Kreder 2805, Esperanza, Santa Fe (3080). Tel.: +54 903496420639 int. 155. E-mail: nrossler@fca.unl.edu.ar

2.- Ingeniero Agrónomo de la Cooperativa de Tamberos “Las Dos Provincias”. Dirección: Corrientes s/n Colonia Bicha, Santa Fe, Argentina. (C.P 2317) Tel.: +54 903493492726 int 7. E-mail: josegiusiano27@gmail.com. Ingeniero Agrónomo de la Cooperativa Agrícola Ganadera de Morteros Ltd y Asesor Privado de Empresas Agropecuarias. Monseñor Lafitte 51. (2421) Morteros, Córdoba. E-mail: danielblangetti@hotmail.com Manuscrito recibido el 16 de agosto de 2016 y aceptado para su publicación el 11 de octubre de 2016. 